\title{
Ruta Graveolens Flowering Top Oil
}

National Cancer Institute

\section{Source}

National Cancer Institute. Ruta Graveolens Flowering Top Oil. NCI Thesaurus. Code

C71864.

The essential oil extracted from the petals of Ruta graveolens. Ruta graveolens flower oil is used for relief of minor aches and pains of muscles and joints associated with arthritis. 